\title{
Analysis of technical efficiency of small-scale commercial farmers in Vhembe district
}

Muzekenyi, M. ${ }^{1}$, Zuwarimwe, J. $^{2}$ and Kilonzo, B.M. ${ }^{3}$

Corresponding Author: M Muzekenyi. Email: Muzekenyi.m@yahoo.com

\begin{abstract}
Small-scale commercial farmers are regarded as the strategic avenue to achieve meaningful development in rural areas of South Africa. The government acknowledged that the inclusion of small-scale commercial farming in its development strategies. The paper aims to measure the efficiency of small-scale commercial farming enterprises in Vhembe District in Limpopo Province. Quantitative data were collected from 217 small-scale commercial farmers using structured questionnaires. The data were standardized using a farming enterprise budget system and analysed using the maximum likelihood and stochastic frontier analysis. The results revealed that aggregate output was positive and significantly influenced by age, education level, farm experience, farm labour, and government grants. However, the projected stochastic production frontier model combined with the efficiency parameters showed that labour and credit computed a negative effect on technical efficiency. The results indicated that the average level of technical efficiency ranged between $20 \%$ and $96 \%$ with a mean of $54 \%$. This indicates that there is potential to increase production among small-scale commercial farmers in the study area by $46 \%$ through efficient use of existing resources. As such, the local government should provide necessary supports such as formal agriculture training, access to credit and information to increase productivity.
\end{abstract}

Keywords: Technical efficiency, Stochastic frontier analysis, small-scale commercial farming

\section{INTRODUCTION}

South African agriculture sector is dual, dominated by a well developed commercial farming sub-sector on the one hand and the communal farming sub-sector mainly practised by resourcepoor small-scale commercial farmers (Gwebu, 2018:56). Small-scale commercial farming is, however dominating in rural areas where about $70 \%$ of the most impoverished population are found (Gwebu, 2018:58). The commercial sub-sector consists of large-scale farmers using well-advanced technology and machinery (Khapayi \& Cellers, 2016:27). Small-scale commercial farming has been earmarked as a strategic sub-sector for inclusive growth in rural

\footnotetext{
${ }^{1}$ Researcher: Smart Group Consultants, 31 Newquay St Old Mutual Alberton, Gauteng South Africa, Tel: +27 68115 8556: Email: Muzekenyi.m@yahoo.com, ORCID: 0000-0002-5340-3220

2 Senior Lecturer: University of Venda, Institute for Rural Development, Address: P.O.BOX X5050 University of Venda, Tel: +27 73514 2569, Email: jethro.zuwarimwe@mvulaunivenac.onmicrosoft.com, ORCID: $\underline{0000-}$ 0002-8196-5896

${ }^{3}$ Senior Lecturer: University of Venda, Institute for Rural Development, Address: P.O.BOX X5050 University of Venda, Tel: +27 82518 2676, Email: Beata.Kilonzo@univen.ac.za, ORCID: 0000-0001-5336-1270
} 
areas. As envisioned in South Africa's National Development Plan Vision 2030, Sustainable Development Goals 1 and 2, and Agenda 2063, small-scale commercial farming can play a significant role in rural development (Casazza \& Chulu, 2016:5; Dhlamini, 2017:8; Agriculture Outlook, 2018:3). Thus, improving small-scale commercial farming productivity can help to achieve the aforementioned national programs. As such, the maximising output produced using the least amount of inputs (technical efficiency) can be a congruent avenue to achieve meaningful development. According to Itam and Ajah (2015:2), technical efficiency is improved with techniques such as agriculture training, access to information and farm management skills. Thus, the paper used an input-output approach to identify the variables which would best estimate productivity and efficiency based on methods developed to estimate frontier production using Stochastic Frontier Analysis (SFA) as described by (Abdul-Salam \& Phimister, 2016:6). Unlike, Data Envelope Analysis which uses non-parametric methods to construct the best practice frontier and requiring the use of robust Time series data, SFA as a parametric approach requires assuming a specific function which shows how outputs can be derived from and multiple inputs (Dhlamini, 2017:8). As such, a set of variables (inputs and outputs) that are necessary for production efficiency measurements are described below. The two-error component stochastic frontier production function suggested to represent technical inefficiency was employed as shown below:

The cost of inputs is expressed as;

$C=f\left(x_{1}+\ldots . . x_{n}\right)$

Aggregate output is thus expressed as;

$Y=f\left(x_{1}+\ldots . . x_{n}\right)$

\section{1}

Where;

$C$ denotes total cost per each farm

$X_{1} \ldots X_{n}$ denotes a combination of fixed and variable cost

In this regard, the production efficiency model is such that the potential production $\mathrm{Y}$ is constrained by stochastic quantity $\mathrm{f}\left(\mathrm{X}_{\mathrm{i}}, \beta\right)$ exp $\left(\mathrm{Z}_{\mathrm{I}}\right)$ justifying the term stochastic frontier. Furthermore, the random error $U_{i}$ is independent and identically distributed. In this regard, the production frontier is thus given as;

$Y=f\left(X_{p}\right)$

Where;

$\mathrm{Y}$ denotes output and $\mathrm{X}_{\mathrm{n}}$ is a vector of variable inputs

The TE input vector $\left(\mathrm{X}_{1}\right)$ for a predicted level of output $(\mathrm{Y})$ is derived by solving concurrently the equation (1.2. ) and the input $\mathrm{XP}_{\mathrm{P}} / \mathrm{Xi}=\mathrm{M}_{\mathrm{i}}(\mathrm{i}$ is greater than 1$)$ and $\mathrm{M}_{\mathrm{i}}$ is the ratio of the inputs 
$\mathrm{X}_{\mathrm{n}}$ and $\mathrm{X}_{\mathrm{i}}$ at output $\mathrm{Y}$. In the instance when the production frontier is self-dual as assumed under Cobb-Douglas function, the cost frontier is expressed as;

$\mathrm{Cs}=\mathrm{f}(\mathrm{G}, \mathrm{O})$

Where;

Cs denotes the lowest cost associated with farm production of output $\mathrm{O}$

$\mathrm{G}$ denotes input prices vector.

In this regard, applying differentiation technique which allows estimating the rate of change, we obtain,

$\Delta \mathrm{Cs} / \Delta \mathrm{G}=\mathrm{X}_{\mathrm{p}}(\mathrm{G}, \mathrm{O})$

Substituting a firm's input costs and output quantity into equation 1.4, the computed equation gives economic efficiency $\left(\mathrm{X}_{\mathrm{n}}\right.$ ' $\left.\mathrm{G}\right)$ and $\left(\mathrm{X}_{\mathrm{i}}\right.$ ' $\left.\mathrm{G}\right)$ input combination for a farm' output. Equations 1.1 - 1.4 for measuring costs, they can be used to derive TE and EE indices as;

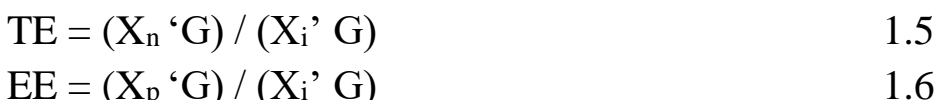

To this end, the productivity of small-scale commercial farmers continues to be very low compared with that of large commercial farmers (Khapayi \& Celler, 2016:27). In Zambia, a study by Musaba and Bwacha (2014:104) on technical efficiency of small-scale maize production revealed that the majority of farmers in this band are inefficient. As such, there is potential for growth in maize production in Zambia. A study by Idgekele, Daramola AND Falusi (2018:87) revealed that rural farmers are found to be more technically efficient than farmers in urban areas in Nigeria. Even though farmers from urban centres have better access to production inputs such as fertilizers, rural farmers have relative large farms and were found to be more efficient (Idgekele et al., 2018:89). Furthermore, a study by Ngombe (2017:347) revealed that some regions in Zimbabwe were more technically efficient than in other regions. Regions with aspects such as access to cheap inputs, cheap labour and access to information (Moyo, 2011:493; Zamasiya, Mango, Nyikahadzoi and Siziba, 2014:49). However, other regions with low efficiency had no access to cheap inputs which affected their production costs hence lower technical efficiency (Moyo, 2011:494).

There is a consensus that the agriculture subsector's growth can make a significant impact on the inclusive green growth in terms of building strong economies and in the process reducing poverty, unemployment and nurturing natural resources (Moshi, 2014:2; Chauke, Motlhatlha, Pfumaramba \& Anim, 2013:582; Abdul-Salam \& Phimister, 2016:9). South Africa has managed to achieve its national commitment in line with CAADP (2013) to invest at least 10\% of its GDP towards agriculture sector (Agriculture Outlook, 2018:4; Market Intelligence Report, 2018:6). As such, small-scale commercial farming has been earmarked as one strategic sector for rural development (Alliance for Green Revolution in Africa: AGRA, 2018:7). 
However, there is limited information regarding small-scale commercial farming productivity in rural areas such as the VDM in Limpopo, South Africa.

Small-scale commercial farming productivity as the optimal use of resources can be regarded as a comprehensive way to reduce poverty, hunger and unemployment in rural areas (Market Intelligence Report, 2018:4). Introducing productive farming in small-scale commercial farming can help in achieving the expected impact, and this can be achieved if factors associated with inefficient farming among farmers are known and addressed as such. While a number of studies have been conducted across Africa, (Musaba \& Bwacha, 2014:106; Ngombe, 2017:348; Gwebu, 2018:58; Idgekele et al., 2018:90; Dessale, 2019:4), there is no evidence that supports the role of the small-scale commercial farming subsector. Thus, the aim of the paper was to measure the current level of productivity by estimating input-output ratio (how inputs are converted into outputs- technical efficiency) and allocative efficiency ( the effectiveness of these farmers to optimally allocate the resources and maximise output) in the VDM.

\section{METHODOLOGY}

\subsection{Study area}

The research was carried out in Vhembe District, Limpopo province that is made up of four local municipalities, namely Thulamela, Musina Makhado, Collins Chabane Local Municipalities. Situated between latitudes 22.76960 South and 29.9741 East, has a population of 1312427 dominated by females (55\%). Vhembe District covers an estimated area of $25596 \mathrm{~km}^{2}$ (RDLR, 2016:2), representing 11\% of the country's land and agriculture is the leading sector in this province. According to Limpopo Department of Agriculture and Rural Development (2016:3), agriculture is one of its main economic drivers. The varied climatic conditions allow farmers to produce a wide range of cash crops (Department of Agriculture and Land Reform: DALR, 2019:3) hence about 70\% of the households produce cash crops (Kem, 2017). In the district farming is being practised by large scale -commercial, small scale commercial and subsistence farming systems (DALR, 2019:5).

\subsection{Sampling procedure and study materials}

Multi-stage sampling techniques were used to select the respondents to the study. First, four municipalities in Vhembe District were divided into clusters and purposively selected depending on the type of farming practised (small-scale mixed farming, crop and livestock farming). Second, since the target population small-scale farmers producing for the market were further purposively selected based on the farming motive and type of farming practised. Third, respondents were randomly selected with Thulamela having 74, respondents Makhado 52, Collins Chabane 50 and Musina 41, giving a total sample size of 217. Subsequently, structured questionnaires were pretested to check to do information seeking and testing the 
survey instrument for validity and reliability. Subsequently, the results from the pretesting phase were subjected to a reliability test and a Cronbach alpha coefficient of .87 . The general rule of reliability states that a Cronbach's alpha of .70 and above is regarded as good (ZuranoCerevello., 2018:1116). Thus, a Cronbach's alpha of .87 rendered the instrument used well for the study. The collected data from phase one was objectively pretested, and a structured questionnaire was constructed to meet the objectives of the study. The instrument was subdivided into three sections, socio-economic characteristics, farming statistics and enterprise budget farming entrepreneurial skills and challenges section.

\subsection{Data analysis}

The collected data was standardised using a farm enterprise budget system in Excel. First, to check the profitability of small-scale farmers, the farm enterprise budget system was used and the outcome revealed the profit margins as showed in Table 1.1. Subsequently, analysis of variance (ANOVA) was used to check if there is any difference in costs incurred by mixed farmers, crop farmers and livestock farmers in Vhembe District. Technical and economic efficiency were estimated using stochastic frontier analysis and later, the data was subjected to maximum likelihood estimations in order the determine variables which affects efficiency in small-scale commercial farming. The results of the study are presented below.

\section{RESULTS AND DISCUSSION}

The efficiency of a farm/production unit can be measured through the capability of a farm to use inputs in optimal proportions, given their corresponding prices) hence, Technical Efficiency (TE) (Ngombe, 2017:348). However, to understand the level of farm profitability, the paper employed farming budgetary techniques which also shows variable and fixed inputs used by farmers which also can be used to identify the inputs costs and the corresponding revenue.

\subsection{Small-Scale Commercial Farming Budgetary Technique and Cost Return}

The establishments of farming budgetary techniques are crucial requirements for effective farming planning (FAO, 2018:3). The budgetary technique shows the revenues received by farmers and the costs incurred when producing. Thus, the data obtained were analysed using budgetary techniques, and the results are presented in Table 1.1.

The results in Table 1.1 show results for small-scale commercial farming budgetary analysis. Considering the computed average costs incurred by small-scale commercial crop, livestock and farmers practising mixed farming, the results show that variable costs form the most significant portion of the total cost. Small-scale commercial livestock farmers recorded the most substantial variable costs of $75 \%$, followed by crop farmers $(74 \%)$ and mixed farmers $(67 \%)$. In terms of crop producers, costs of inputs (32\%) recorded the most considerable costs 
followed by the cost of labour (17\%). As for Livestock producers, household expenses recorded the highest cost in this type of farming. Farmers practising mixed farmers' inputs cost recorded the highest (29\%), followed by the cost of labour (16\%). As for fixed costs, the results in Table 1.1 show that the computed average costs are less than variable costs with the crop, livestock and mixed farmer computing $17 \%, 25 \%$ and $33 \%$ respectively. Thus, small-scale commercial farmers are incurring more costs from variable expenses rather than fixed expenses.

In terms of profits, crop farmers recorded an average positive profit of R4018 (USD 268) which marked the cost ratio of $0.029 \%$ and the gross ratio of $34.8 \%$. Similarly, mixed farmers computed an average profit of R76 663 (\$5110), which gave a cost ratio of $0.55 \%$ and the gross ratio of $1.8 \%$. However, on average, livestock producers recorded a loss of R34 176 (\$2277) and the household expenses (35\%) accumulated the most considerable portion of variable costs. The variation on revenue generated may be linked to high variable costs across all types of small-scale commercial farmers in the study. Considering that VDM is predominantly rural; the majority of the farmers use intensive labour which may be the reason for high labour costs as shown in Table 1 Similarly, Dorward (2013) states that rural agriculture is highly dependable on family labour which is exacerbated by a lack of relevant capital to buy machinery. In this regard, the use of intensive labour for farming may seem feasible for small-scale commercial farming, but in turn, it leads to high variable costs which ultimately reduce the profits. Likewise, costs of inputs were also high across all types of farming.

Fertilizer, seeds and chemicals are essential for small-scale commercial farming, but the corresponding costs incurred are indeed leading to low-profit margins. Khapayi and Cellers (2016:33) state that high input costs are some of the limiting factors preventing emerging farmers from progressing to commercial agricultural farming. Thus, it is evident that smallscale commercial farmers are affected by high input costs which limits them from developing their businesses. In turn, high variable costs have also affected their profitability as these costs are above $60 \%$ of the total costs incurred (Table 1.1). Considered as such, Total Variable Costs formed the bulk of Total costs as compared to Total Fixed Costs which shows that small-scale commercial farming in VDM can be improved if these farmers are cost-efficient. 
Vol. 49 No. 1, 2021: 91-104

http://dx.doi.org/10.17159/2413-3221/2021/v49n1a10780

(License: CC BY 4.0)

Table 1 Small-scale Commercial Farming Enterprise Budget $(\mathbf{n}=217)$

\begin{tabular}{|c|c|c|c|c|c|c|c|}
\hline & & CROP & & LIVESTOCK & & MIXED FARMING & \\
\hline & Description & Value (R) & $\%$ & Value (R) & $\%$ & Value (R) & $\%$ \\
\hline \multirow{5}{*}{$\begin{array}{l}\text { Variable } \\
\text { Costs }\end{array}$} & Average labour cost & $24000(\$ 1600)$ & 17 & $33000(\$ 2200)$ & 20 & $21546(\$ 1436)$ & 16 \\
\hline & $\begin{array}{l}\text { Average inputs cost } \\
\text { (Water, electricity, fertilizers, } \\
\text { pesticides and seeds) }\end{array}$ & $45130(\$ 3009)$ & 32 & $21087(\$ 1406)$ & 13 & $40040(\$ 2669)$ & 29 \\
\hline & Average utility cost & $15000(\$ 1000)$ & 11 & $12435(\$ 829)$ & 7 & $17865(\$ 1191)$ & 13 \\
\hline & Average household Expenses & $18800(\$ 1254)$ & 13 & $57896(\$ 3860)$ & 35 & $13245(\$ 883)$ & 10 \\
\hline & Average total Variable Costs & $102930(\$ 6862)$ & 74 & $124418(\$ 8295)$ & 75 & $92656(\$ 6177)$ & 67 \\
\hline \multirow[t]{6}{*}{ Fixed Costs } & Average drawing costs & $15780(\$ 1052)$ & 6 & $19876(\$ 1325)$ & 12 & $34532(\$ 2302)$ & 25 \\
\hline & $\begin{array}{l}\text { Average other fixed } \\
\text { Costs (insurance, life insurance \& } \\
\text { credit payments) }\end{array}$ & $21000(\$ 1400)$ & 10 & $21908(\$ 1462)$ & 13 & $10363(\$ 691)$ & 8 \\
\hline & Average total fixed cost & $36780(\$ 2452)$ & 16 & $41784(\$ 2786)$ & 25 & $44895(\$ 2993)$ & 33 \\
\hline & Average total cost & $139710(\$ 9314)$ & & $66202(\$ 4413)$ & & $137551(\$ 9170)$ & \\
\hline & Average total sales & $143728(\$ 9582)$ & & $132035(\$ 8802)$ & & $214214(\$ 14281)$ & \\
\hline & Profit (ATR - ATC) & R4020 (\$268) & & $(-34167)(\$ 2277)$ & & \multicolumn{2}{|l|}{$76663(\$ 5110)$} \\
\hline
\end{tabular}

Source: Authors Survey (2019)

$\$$ denotes United States Dollars (USD)

$\mathrm{R}$ denotes South African Rand (ZAR)

Exchange $=\mathrm{R} 15$ is equivalent to $\$ 1$ (flexible exchange rate according to Reserve Bank of South Africa in February 2020) 


\subsection{Cost variation in small-scale commercial farming}

The study further assessed if there is any difference between the costs incurred by these farmers. The farming type was used as an independent variable and total costs as the dependent variable. The first step taken was to check sample information (descriptive statistics results). As shown in Table 2, the average score for the crop, mixed, and livestock farming of 112217, 112245,123052 respectively are relatively equal. This shows that livestock farmers expressed more total costs as compared to mixed and crop farmers. In terms of mixed farming and crop, the computed average scores were relatively equally. However, all farming types means are inbetween the lower and upper bound interval at 95\% confidence level. All three types of farming had relatively equal means. The computed standard deviations of 54667 (crop), 65318 (mixed) and 64775 (livestock) show that the deviations between mixed and livestock farming. Table 3 shows the results for ANOVA, which measures if there is any statistical difference, the total costs incurred by these farmers. The computed p-value of 0.56 is higher than $5 \%$. Hence, the study concludes that there is no statistical difference in total costs incurred by all types of farmers. This implies that small-scale commercial farmers incur relatively equal costs regardless of the type of farming practice.

Table 2 Total cost variation in small-scale commercial farming $(n=217)$

\begin{tabular}{|l|l|l|l|l|l|}
\hline \multicolumn{7}{|l|}{ ANOVA } \\
\hline Small-scale commercial farming total costs & df & Mean Square & F & Sig. \\
\hline & Sum of Squares & 2 & 2282195128.047 & .577 & .563 \\
\hline Between Groups & 4564390256.094 & 215 & 3957308793.580 & & \\
\hline Within Groups & 846864081826.100 & 217 & & & \\
\hline N & & & & \\
\hline
\end{tabular}

Source: Author's Survey 2019

Several factors have been identified in literature which prevents small-scale farmers from scaling up their production. The results support Khapayi and Celliers (2016:27), who revealed that high transaction costs which include high inputs and transport costs are hindering smallscale farmers from developing. Chauke et al. (2013:583) also stated that a lack of skills to interpret market information in small-scale farming is resulting in high operational costs in this subsector. The study concludes that high costs incurred in this sub-sector might be caused by a lack of financial skills.

Table 3 Total costs variation among mixed, livestock and crop farming enterprises (n=217) Source: Author's Study (2019)

\begin{tabular}{|l|l|l|l|l|}
\hline Farming type & N & Mean & Std. Deviation & Std. Error \\
\hline Crop & 50 & 112217.26 & 54664.988 & 7730.797 \\
\hline Mixed & 116 & 112244.64 & 65318.487 & 6064.669 \\
\hline Livestock & 51 & 123052.75 & 64775.189 & 9070.341 \\
\hline Total & 217 & 114778.48 & 62783.744 & 4262.038 \\
\hline
\end{tabular}




\subsection{Analysis of Small-scale Commercial Farming Enterprises' Technical Efficiency}

The computed statistics of TE estimates are presented in Table 1.4. The results show that the TE of small-scale commercial farmers ranges between 10.18 and 98.39, with an average of $54.25 \%$ (Table 1.2). The efficiency distribution level indicates that $41 \%$ of the farmers are in the category $31-50 \%$ TE level. Important to note is the gender dimension which shows that more male farmers $(27 \%)$ are in the range of $31-50 \%$ TE level compared to $17 \%$ of the female farmers. With respect to those having the lowest TE level (1-30\%,) there are more male farmers (23\%) compared to female farmers (12\%) implying that female farmers'enterprises are more effeicient given the same quantity of resources and working under same conditions. Similar trends were noted within the 51-70\% TE level where there were more female farmers $(11 \%)$ compared to $4 \%$ male farmers. Furthermore, within the $71-100 \%$, TE level there were also more female farmers $(7 \%)$ compared to male farmers $(2 \%)$. To this end, the majority of the farmers (both male and female) are operating below the production frontier which shows that there is still more room to improve their production processes by $43.75 \%$ given the mean score of $43.75 \%$ and the available resources in VDM.

The results in Table 4 imply that small-scale commercial farmer's productive capacity factors could be influenced by their inability to utilise the available resources such as inputs, education, government subsidised inputs and financial support. However, most of the farmers were found to be technical inefficient (Table 1.4). The study results support, Lekunze and Luvhengo (2016:13); Glover and Jones (2019:121) surveys which revealed that the majority of emerging commercial farmers are technically inefficient. Also, Glover and Jones (2019:122) revealed that small-scale commercial farmers able to improve their productivity through training on cost-effective methods in farming. To this end, the average technical efficiency mean as indicated above shows that there is room for female and male small-scale commercial farming to increase output through efficient use of resources at their disposal.

Table 4 Distribution of technical efficiency of small-scale commercial farmers in Vhembe District (n=217) Source: Authors Survey 2019

\begin{tabular}{|c|c|c|c|}
\hline TECHNICAL EFFICIENCY INTERVAL & GENDER & TOTAL & Proportion (\%) \\
\hline \multirow[t]{2}{*}{$1-30$} & Male & 49 & $23 \%$ \\
\hline & Female & 27 & $12 \%$ \\
\hline \multirow[t]{2}{*}{$31-50$} & Male & 53 & $24 \%$ \\
\hline & Female & 36 & $17 \%$ \\
\hline \multirow[t]{2}{*}{$51-70$} & Male & 8 & $4 \%$ \\
\hline & Female & 23 & $11 \%$ \\
\hline \multirow{2}{*}{$71-100$} & Male & 4 & $2 \%$ \\
\hline & Female & 18 & $7 \%$ \\
\hline \multicolumn{2}{|l|}{ Mean $=54,25$} & & \\
\hline Min $=24,37$ & & & \\
\hline
\end{tabular}


$\operatorname{Max}=94,34$

The study further assessed economic efficiency to check the economic state of small-scale commercial farmers in rural areas. The results are presented in Table 5.

\subsection{Determinants of Technical Efficiency}

Table 5 shows the results for estimates of the frontier production function. the results were obtained using OLS estimates of the average production function for the sampled small-scale commercial farmers in VDM. The computed results revealed that aggregate small-scale commercial farming output is significantly affected by several variables. The Coefficients of farmers' age, education, land size, farming experience, labour, and government grants were positively associated with farm output at $5 \%$ level of significance. Subsequently, the likely hood ratio of production efficiency of the model of $76 \%$ and an asymptotic significance value of 0.01 . This implies that at most $76 \%$ or the variation in the given variables is explained by the model. As such, the age of the farmer is usually associated with farm experience. Both age and experience were positively correlated to farm output. Since most of the farmers are above 41 years (Table 1). Thus, age may have contributed to the positive effect since these farmers are considered experienced due to many years of practising farming. Similarly, Ferreira (2017:2) noted that farmer's experience is directly linked to the age and the higher the age, the more experienced the farmer becomes. Agarwal (2018:57) also conducted a comparative study between-group farms and individuals family farmers, and the results revealed that the age of the farmer contributed positively to both group farms and individual farms. Thus, the study concludes that age and farm experience are correlated and can positively influence farming productivity

Subsequently, education level is directly linked to skills acquisition. Since most the farmer does have at least a certain form of education (See Table 1). Education is regarded as a significant element for productivity in farming since different skills such as farm management and bookkeeping are often taught. The results concur with Ferreira (2017:1) who states that there are positive returns to eduction in agricultural productivity and the overall value of farming produce. Similarly, Abdu-Raheem and Worth (2011:14) study revealed that as the educational level increases, farming output increases. Thus, the education level was found to be the third-highest variable which positively influences aggregate farm income.

In terms of land size, farm size is directly linked to bigger output since the farmer can cultivate different types of crops and livestock. Most rural farmers are practising farming on community and freehold land which in turn reduces the cost of production. Thus, land size can play a significant role in farming productivity. Rural farmers usually use cheap foreign cheap labour and family members to work on the farms. As such, the use of cheap foreign and family labour reduces the variable cost incurred by the farmer hence increases the returns to farm output. Thus, as stated by Notle and Ostrernmier (2017:433), farmers target cheap foreign labour 
instead of local labour which is not formally recorded. This may be the reason for the high unemployment rate in rural areas due to unrecorded foreign labour. Most farms are employing cheap foreign labour, and the reluctance of youth to work in farms or start Agribusinesses may be another reason for high youth unemployment rates in rural areas.

Government support is in the form of grants and subsidies inputs are regarded as cash injections in small-scale farming. Access to these grants means an increase in farm production finances hence may positively affect farm production leading to an increase in output. Financial support expedites Agribusinesses as it permits farmers to purchase inputs and cover operating expenses (World Bank, 2018:2). Accordingly, the results of the study show that government support and farmer's aggregate income are highly correlated. A study by Sumner (2019:2) on agricultural subsidy programs revealed that government intervention in farming is fundamental for farming development.

Table 5 Determinants of technical efficiency in small-scale commercial farming productivity $(n=217)$

\begin{tabular}{|l|l|l|l|l|}
\hline Variables & Coefficients & SE & T-static value & Sig. (p-value) \\
\hline Age (years of the farmer) & 0.6123 & 0.200 & $3.059^{* * *}$ & 0.023 \\
\hline Education level & 0.372 & 0.029 & $2.483^{* * *}$ & 0.034 \\
\hline Household size & -0.047 & 0.083 & 0.566 & 0.231 \\
\hline Land size (hectare) & 0.239 & 0.092 & $2.591^{* * *}$ & 0.031 \\
\hline Farm experience (years) & 0.347 & 0.154 & $2.253^{* * *}$ & 0.047 \\
\hline $\begin{array}{l}\text { Farm Labour (Monetary } \\
\text { costs, ZAR) }\end{array}$ & 0.453 & 0.198 & $2.543^{* * *}$ & 0.021 \\
\hline Access to Credit & 0.021 & 0.034 & 0.617 & 0.895 \\
\hline Government support & 0.712 & 0.231 & $3.082^{* * *}$ & 0.01 \\
\hline Likely hood ratio & 0.76 & & & \\
\hline Asymp Sig: & 0.01 & & & \\
\hline
\end{tabular}

Source: Author's Survey 2019

$* * *$ Sig at $5 \%$

\section{CONCLUSION}

The study revealed several outcomes regarding the efficiency of small-scale commercial farming in VDM. First, high costs of production are incurred by small-scale commercial farmers in VDM. These costs are mostly derived from variable costs. As for technical efficiency, the implication of the study on small-scale commercial farming productivity, the majority of the farmers are technically inefficient. Furthermore, majority of the farmers were also found to be economically inefficient. This is a true reflection of the fact that there is vast room for improvement in small-scale commercial farming productivity. The results on determinants of technical efficiency revealed that the age of the farmer, education level, farm experience, farm labour and government grants were found to have a significant positive effect on aggregate farm output. However, family labour and credit computed the least effect on farm 
output. The study concludes that small-scale commercial farming productivity can be improved through better allocation of the available resources, mainly land, labour and farm inputs. Access to better markets and training in farm management and marketing can improve productivity in small-scale commercial farming.

\section{RECOMMENDATIONS}

Small-scale commercial farming productivity should be covered in agriculture policies. The emphasis should be placed on including strategies which enable farmers to be productive such as skills acquisition and adoption of the latest technology in rural agribusinesses. In this regard, productivity should be calculated by the ability of the farmer to optimally convert inputs to maximise output. Thus, limiting productivity to land use may impend the production capacity of small-scale commercial farmers in rural areas. Agricultural research and productivity training systems should be put in place and be regularly promoted in rural areas since smallscale commercial farming is constituted of the diversity of farmers. This includes enabling policy mix, which includes financial, access to productive land and agricultural measures specifically to develop this sub-sector. The building of strong government intervention, farming stakeholder participation in policy formulation and adequate support for small-scale commercial farmers' schemes in rural areas. Thus, small-scale commercial farmers should be supported to have access to critical factors of production (water and productive land) which enable agribusiness development in rural areas. Furthermore, there is a need to put economic measures which enable small-scale commercial farmers to have access to supply chain in local and national markets.

\section{REFERENCES}

ABDU-RAHEEM, K. A. and WORTH, S. H. 2011. Household food security in South Africa: evaluating extension's paradigms relative to the current food security and development goals. S Afr. Jnl. Agric. Ext. [online]. 2011, vol.39, n.2, pp.91-103. ISSN 2413-3221

ABDUL-SALAM, Y. \& PHIMISTER, E. 2016. Efficiency Effects of Access to Information on Small-scale Agriculture: Empirical Evidence from Uganda using Stochastic Frontier and IRT Models. Journal of Agriculture economics., 68(2):1-15

AGARWAL, B. 2018. Can group farms outperform individual family farms? Empirical insights. World Development, 108(2018):57-73

AGRICULTURE OUTLOOK. 2018. BFAP Baseline agricultural outlook 2018 - 2027, Pretoria: BFAP

ALLIANCE FOR GREEN REVOLUTION IN AFRICA. 2017. The Business of Smallholder Agriculture in Sub-Saharan Africa. [viewed August 2019]. Available from: https://agra.org/wp-content/uploads/2017/09/Final-AASR-2017-Aug-28.pdf 
CASAZZA, A. \& CHULU, O. 2016. "Aligning the Sustainable Development Goals (SDGs) to the National Development Plan (NDP): Towards domestication of the SDGs in South Africa, Johannesburg: Wits School of Governance

CHAUKE, P., MOTlHATlHA, M., PFUMARAMBA, T. \& ANIM, F. 2013. Factors influencing access to credit: A case study of smallholder farmers in the Capricorn district of South Africa. African Journal of Agricultural Research, 8(7): 582-585

DESSALE, M. 2019. Analysis of technical efficiency of smallholder wheat-growing farmers of Jamma District, Ethiopia. Journal of Agriculture \& Food Security, 8(1):2-8

DEPARTMENT OF RURAL DEVELOPMENT AND LAND REFORM. 2016. Spatial Planning and Land Use Management: Rural Development, Pretoria: Department of Rural Development and Land Reform

DEPARTMENT OF LAND REFORM SOUTH AFRICA. 2019. National Minimum Wage. [viewed August 2019]. Available from: http://www.labour.gov.za/DOL/legislation/acts/national-minimum-wage/nationalminimum-wage

DHLAMINI, L. 2017. Integrating agenda 2030 for Sustainable Development Goals (SDGs) into regional and national development plans and strategies, Pretoria: UNDP

DORWARD, A. 2013. Agricultural labour productivity, food prices and sustainable development impacts and indicators. Food and Agriculture Policy, 39(2013):40-50.

FERREIRA, T. 2017. Does Education Enhance Productivity in Smallholder farming. Johanessburg, Stellenbosch University

FOOD AND AGRICULUTURE ORGANISATION. 2018. Budgetary control: [viewed August 2019]. Available from: http://www.fao.org/3/w4343e/w4343e05.htm

GLOVER, S. \& JONES, S. 2019. Can commercial farming promote rural dynamism in subSaharan Africa? Evidence from Mozambique. World Development, 114(12): 110-121

GWEBU, J. 2018. Metafrontier analysis of commercial and smallholder tomato production: A South African case. Scielo, 114(7): 55-68

IDGEKELE, A., DARAMOLA, A. \& FALUSI, A. 2018. Technical efficiency of small scale farmers: An application of the stochastic frontier production function to rural and urban farmers in Ondo State, Nigeria. International Economic Journal, 20(1): 87-107

ITAM, K. O. \& AJAH, A. E. 2015. Technical Efficiecny Analaysis of Small Scale Cassava Farmers in Cross River State, Nigeria: A Stochastic Production Frontier Approach. Cross River State, Research Gate

KEM, S. 2017. Commercialization of Smallholder Agriculture in Cambodia: Impact of the Cassava Boom on Rural Livelihoods and Agrarian Change. Queensland, University of Queensland 
KHAPAYI, M. \& CELLIERS, P. 2016. Factors limiting and preventing emerging farmers to progress to commercial Agricultural farming in the King William's Town area of the Eastern Cape Province South Africa.. Journal for Agriculture, 44(1):25-41

LEKUNZE, J. \& LUVHENGO, U. 2016. Measuring Technical Inefficiencies in Small-scale Small Stock Production in Dr Ruth Segomotsi Mompatsi District, North-West Province, South Africa. Trends in Agricultural, 9(1-3), pp. 13-20

MARKET INTELLIGENCE REPORT. 2018. Sustainable Agriculture. [viewed August 2019]. Available from: https://www.greencape.co.za/assets/Uploads/GreenCape-SustainableAgriculture-MIR-FINAL-WEB-24-5-2018.pdf

MOSHI, H. 2014. Sustainable and inclusive growth in Africa: Industrialization a must. [viewed August 2019]. Available from: http://www.tips.org.za/files/sustainable and inclusive growth in africa - moshi.pdf

MOYO, S. 2011. Three decades of agrarian reform in Zimbabwe. The Journal of Peasant Studies, 38(3): 493-531

MUSABA, E. \& BWACHA, I. 2014. Technical Efficiency of Small Scale Maize Production in Masaiti District, Zambia: A stochastic Frontier Approach. Journal of Economics and Sustainable Development, 5(4):104-111

NOTLE, K. AND OSTERNMEIR, M. 2017. Labour Markets Effects of Large-scale Agricultural Investment: Conceptual Considerations and Estimated Employment Effects. World Development Journals, 98(12): 430-446

NGOMBE, J. 2017. Technical efficiency of smallholder maize production in Zambia: a stochastic meta-frontier approach. Agricultural Economics Research, Policy and Practice in Southern Africa, 21(3):347-365

SUMNER, D. 2019. Agricultural Subsidy Programs. [Online] Available at: https://www.econlib.org/library/Enc/AgriculturalSubsidyPrograms.html

ZAMASIYA, B., MANGO, N., NYIKAHADZOI, K. \& SIZIBA, S. 2014. Determinants of soybean market participation by smallholder farmers in Zimbabwe. Journal of Development Agricultural economics, 6(2):49-58

ZURANO-CERVELLO, P. \& GUILLEN-GOSALBEZ, G. 2018. Eco-efficiency assessment of EU manufacturing sectors combining input-output tables and data envelopment analysis following production and consumption-based accounting approaches. Journal of Cleaner Production, 174(10): 1161-1189 